International Journal of Engineering \& Technology, 7 (3.30) (2018) 330-333
International Journal of Engineering \& Technology
WPC
Website: www.sciencepubco.com/index.php/IJET
Research paper

\title{
The Role of Emotional Intelligence in the Performance of an Organisation with 2 Mediating Variables: a Case Study Approach
}

\author{
Susan Tee Suan, Chin ${ }^{1}$, Prof Dr. Rosman Md Yusoff ${ }^{2}$, \\ ${ }^{1}$ Multimedia University, Melaka, Malaysia \\ ${ }^{2}$ Universiti Tun Hussein Onn, Parit Raja, Batu Pahat, Malaysia \\ *Corresponding author E-mail: tschin@mmu.edu.my
}

\begin{abstract}
As organisations enter the 21 st century, the dynamism of the business environment has certainly increased its pace. The external environment especially the technological element has accelerated the changes in the business platform. Many organisations who are unable to keep up with these changes has to wrap up. Those in the business needs to look for a strong strategic asset which can be used not only for sustainability but to propel the business into higher realms. In the 1980s-1990s, a few studies have highlighted the usage of emotional intelligence as a source of performance among their employees. The purpose of this study is to study the role of emotional intelligence in the performance of an organisation with 2 mediating variables. A case study approach has been used in this study. It was found that with the mediating variables in play, the role of emotional intelligence has certainly enhanced.
\end{abstract}

Keywords: Competitive Advantage; Workplace Environment; Teamwork; Unity; Development

\section{Introduction}

The business environment has been volatile over the past few years. Many changes have taken place, such as changes economic policies, advancement of technology and more free trade agreements being signed and declared. These changes has made the business organisation vulnerable. They have not only to manage their local competitors but also the foreign competitors as well The onus is now on business leaders. The need to sustain and also to go further has intensified. In order to succeed, business leaders need to search for a source of competitive advantage which cannot be easily copied or substituted. As highlighted in one of Malaysia's strategy to achieve the Economic Transformation Programme, employees represent one of the key areas that needs to be developed. Malaysia needs talented manpower in order to be a formidable global player $(1,6,9)$. Emotional intelligence has been said to have a positive impact to individuals in terms of their performances in the workplaces. They are able to work better than those with lower level of emotional intelligence. There are many studies that has been conducted examining the relationship between emotional intelligence and organisational performance but the results were not convincing enough (13). In workplaces, there could also be other factors that are in place, these factors could mediate the relationship. The purpose of this study is to examine the relationship between emotional intelligence and organisational performance with 2 mediating variables.

\section{Emotional Intelligence}

(4) Claimed emotional intelligence is related to performance. He further suggested that individuals with a high level of emotional intelligence tended to perform better than those with a lower level of emotional intelligence. Emotional intelligence refers to an individual's ability to manage not only their own emotions but also of those around them. Based on the Genos Emotional Intelligence construct, there are 5 emotional competencies that can be seen in the workplace (11). These emotional competencies are Emotional Recognition and Expression; Understanding Others Emotions; Emotions Direct Cognition; Emotional Management and Emotional Control. Emotional Recognition and Expression looks into the ability and capability of the individuals to identify their own feelings and being able to express these thoughts or emotions to the people around them. Understanding Others Emotions describes to the ability of the individual to comprehend the emotions and feelings of those around them. Emotions Direct Cognition refers to the extent of the individual to incorporate their emotions or past experiences to decide on issues or to solve problems in the organisation. Emotional Management looks into how the individual is able to manage not only positive emotions but also negative.

\subsection{Emotional Intelligence and Organisational Perfor- mance}

Good interpersonal relationships among co-workers improves the workplace environment. A better organisational climate enables management to plan and predict the performance of their organisation. Studies began in the early 1990s to link emotional intelligence to organisational performance (2). Since it has been sug- 
gested that emotional intelligence improves performance, business leaders are anxious to determine the possibility of using that as a strategy. Organisations face challenges either local or abroad. With more free trade agreements being negotiated and declared, foreign organisations have started to establish their businesses in Malaysia. In the foreign business environment, the business organisation also needs to have their edge, this is for sustainability and future growth. Organisations need to ensure that there is growth and expansion, this would strengthen the market power. The workforce represents a resource that is distinctive, they cannot be copied or substituted. Although there were several studies, findings to confirm the factors that influence the performance of an organisation has been unfruitful. The evidence has been sparse and weak (13). Many possibilities that could take place, one of it is in terms of the chosen country. A majority of early studies were conducted in developed countries but studies that has been conducted in developing countries has been inadequate. The purpose of this study is to conduct this study in a developing country.

\subsection{Mediating Variables}

It has been suggested that there could be intervening variables in the relationship between emotional intelligence and organisational performance. Studies have highlighted 2 mediating variables that could play an important in role in the relationship between emotional intelligence and organisational performance. Studies on organisational citizenship behaviour (14) and job satisfaction (8) are said to be at a nascent stage (7). More studies are encouraged to examine the mediating effects of both these variables. However, there are certain inconsistencies in terms of the findings between job satisfaction to organisational performance $(3,10)$. Some studies found mixed results, while others found the relationship to be insignificant. The inconsistencies could be due to a few factors such as sample size, nature of business activities and target area. Previous target areas includes the agricultural industry (Hashemi, Nadi, Hosseini \& Rezvanfar, 2012) and the information technology industry (8). Not all industries share similar characteristics and these results in differences in their business environment. This could influence the results of the studies. Manufacturing and nonmanufacturing business activities have different business cycles and their customers are different. For the manufacturing industries, their customer could be the retailers. For the non-manufacturing industries, their customers are the end-user which includes household consumers. The demands would be different. Different demands requires different types of actions or behaviours to be perform by the employees. These could have an influence in their level of job satisfaction.

\section{Methodology/Materials}

\subsection{Theoretical Framework}

The variables used in this study are as follows; emotional intelligence (as the independent variable), organisational performance (as the dependent variable), job satisfaction (mediating variable 1) and organisational citizenship behaviour (mediating variable 2). For the purpose of this study, the parallel multiple mediation analysis would be used to study the effects of the mediating variables. The relationship between emotional intelligence and organisational performance will be considered as the direct effects. While the pathway in which emotional intelligence exerts its influence through the mediating variables will be considered as the indirect effects.

\subsection{Target Population}

A successful manufacturing organisation has been chosen for this study. The organisation has been highlighted as one of the top ten plastic manufacturers in Selangor. Selangor is the top performing state in Malaysia in the plastic manufacturing industry. Malaysia is also one of the top plastic manufacturers in South East Asia. The population in this study are the executives from the particular manufacturing organisation. A total of 110 executives participated in this study. As tabled in Table 1, a majority of the respondents are Males. Most of the respondents are more than 35 years old. More than $80 \%$ of them have worked in the organisation for more than 5 years $(5-10$ years $=27.27 \%$; more than 10 years $=$ $58.18 \%$ ). This could mean that most of the executives are happy to work in the organisation. Questionnaires developed by (11) and (12) have been used to analyse the level of emotional intelligence and organisational citizenship behaviour respectively. The questionnaire developed by (15) has been used to analyse the level of job satisfaction among the executives.

Table 1: Analysis of Respondents

\begin{tabular}{|c|c|c|c|c|}
\hline & & Frequency & Percentage & $\begin{array}{l}\text { Cumulative } \\
\text { Percentage }\end{array}$ \\
\hline \multirow[t]{2}{*}{ Gender } & Male & 70 & & 63.6 \\
\hline & Female & 40 & 46.40 & 100.0 \\
\hline \multirow[t]{5}{*}{ Age Group } & $\begin{array}{l}\text { Less than } 30 \\
\text { years old }\end{array}$ & 2 & & 1.82 \\
\hline & $\begin{array}{l}\text { More than } 31 \\
\text { but less than } 35 \\
\text { years old }\end{array}$ & 18 & 16.36 & 18.18 \\
\hline & $\begin{array}{l}\text { More than } 36 \\
\text { but less than } 40 \\
\text { years old }\end{array}$ & 30 & 27.27 & 45.45 \\
\hline & $\begin{array}{l}\text { More than } 41 \\
\text { but less than } 45 \\
\text { years old }\end{array}$ & 40 & 36.36 & 81.81 \\
\hline & $\begin{array}{l}\text { More than } 46 \\
\text { years old }\end{array}$ & 20 & 18.19 & 100.0 \\
\hline \multirow[t]{2}{*}{ Nationality } & Malaysian & 104 & & 94.54 \\
\hline & $\begin{array}{l}\text { Non-Malaysian } \\
\text { (China) }\end{array}$ & 6 & 5.46 & 100.0 \\
\hline \multirow{2}{*}{$\begin{array}{l}\text { Marital } \\
\text { Status }\end{array}$} & Single & 6 & & 5.46 \\
\hline & Married & 104 & 94.54 & 100.0 \\
\hline \multirow[t]{6}{*}{ Department } & $\begin{array}{l}\text { Human Re- } \\
\text { source and } \\
\text { Administration }\end{array}$ & 21 & & 19.09 \\
\hline & $\begin{array}{l}\text { Finance and } \\
\text { Accounts }\end{array}$ & 12 & 10.91 & 30.00 \\
\hline & Production & 21 & 19.09 & 49.09 \\
\hline & $\begin{array}{l}\text { Sales and } \\
\text { Marketing }\end{array}$ & 20 & 18.18 & 67.27 \\
\hline & Engineering & 30 & 27.27 & 94.54 \\
\hline & $\begin{array}{l}\text { Store and } \\
\text { Logistics }\end{array}$ & 6 & 5.46 & 100.0 \\
\hline \multirow[t]{4}{*}{$\begin{array}{l}\text { Education } \\
\text { Level }\end{array}$} & $\begin{array}{l}\text { Diploma and } \\
\text { Lower }\end{array}$ & 48 & & 43.64 \\
\hline & $\begin{array}{l}\text { Bachelors' } \\
\text { Degree }\end{array}$ & 58 & 52.73 & 96.37 \\
\hline & $\begin{array}{l}\text { Masters De- } \\
\text { gree }\end{array}$ & 2 & 1.82 & 98.19 \\
\hline & $\begin{array}{l}\text { Professional } \\
\text { Qualification }\end{array}$ & 2 & 1.81 & 100.0 \\
\hline \multirow[t]{4}{*}{$\begin{array}{l}\text { Length of } \\
\text { Employment }\end{array}$} & $\begin{array}{l}\text { Less than } 2 \\
\text { years }\end{array}$ & 4 & & 3.64 \\
\hline & $\begin{array}{l}\text { More than } 2 \\
\text { but less than } 5 \\
\text { years }\end{array}$ & 12 & 10.91 & 14.55 \\
\hline & $\begin{array}{l}\text { More than } 5 \\
\text { but less than } 10\end{array}$ & 30 & 27.27 & 41.82 \\
\hline & $\begin{array}{l}\text { More than } 10 \\
\text { years }\end{array}$ & 64 & 58.18 & 100.0 \\
\hline
\end{tabular}

\section{Results and Findings}

Using PROCESS, the results of the parallel multiple mediating effects has been analysed and tabled in Table 2. Before the intervention of the mediating variables, the relationship between emotional intelligence and organisational performance is $r=0.2152$ 
(represented by $\mathrm{c} 1$ in Figure 1). The r values of the other relationships between the variables are represented by a1 (emotional intelligence and organisational citizenship behaviour); a2 (emotional intelligence and job satisfaction); b1 (organisational citizenship behaviour and organisational performance) and b2 (job satisfaction and organisational performance). M1 and M2 represented the mediating variables organisational citizenship behaviour and job satisfaction respectively. These relationship is seen in Diagram 1.

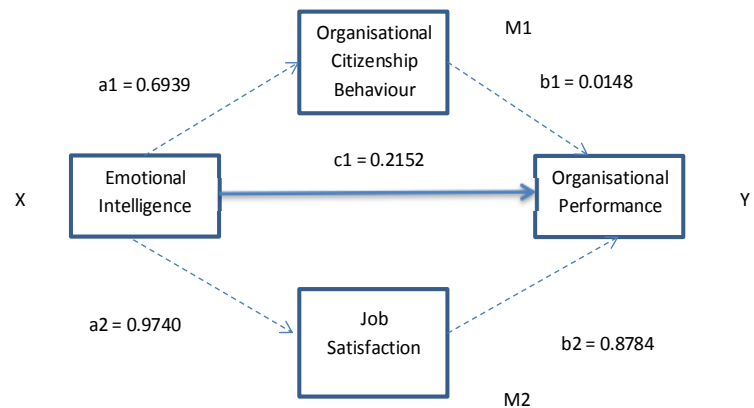

Diagram 1: Parallel multiple mediation model

In terms of the variance, the $\mathrm{R}$ square value for organisational citizenship behaviour is 0.6685 while the $R$ square value for job satisfaction is 0.7734 . Both $\mathrm{R}$ square values showed a large value which reflects the importance of these variables. When both these variables are combined, the $\mathrm{R}$ square value increased to 0.9224 The increase showed the positive impact contributed by both organisational citizenship behaviour and job satisfaction. The Total Indirect Effect of X (or emotional intelligence) on Y (or organisational performance), $\mathrm{c} 2=0.8659$. The Total Effect of $\mathrm{X}$ (or emotional intelligence) on $\mathrm{Y}$ (or organisational performance) $=\mathrm{c} 1+\mathrm{c} 2$. Based on Table 4.16, the Total Effects of X (or emotional intelligence) on $\mathrm{Y}$ (or organisational performance $)=0.2152+0.8659=$ 1.0811. The high value shows that both mediating variables organisational citizenship behaviour and job satisfaction contributes positively to a better working condition and also greater performance in the organisation. Job satisfaction showed an indirect effect of 0.8659 while organisational citizenship behaviour showed an indirect effect of 0.0103 . Based on the indirect values, job satisfaction was found to have a higher indirect value which showed the importance it plays in enhancing the performance of the organisation. See Table 2 .

Table 2: Mediation effects on the relationship between emotional intelligence and organisational performance

\begin{tabular}{|c|c|c|c|c|c|c|c|}
\hline $\begin{array}{l}\text { Out- } \\
\text { come }\end{array}$ & $\mathrm{OCB}$ & & & & & & \\
\hline \multicolumn{8}{|c|}{ Model Summary } \\
\hline & $\mathrm{R}$ & R-sq & $\mathrm{F}$ & $\mathrm{df1}$ & $\mathrm{df} 2$ & $\mathrm{P}$ & \\
\hline & .6685 & .4469 & 87.2786 & 1.0000 & 108.0000 & $\begin{array}{c}.0 \\
00 \\
0\end{array}$ & \\
\hline \multicolumn{7}{|l|}{ Model } & \\
\hline & coeff & se & $\mathrm{t}$ & $\mathrm{p}$ & LLCI & $\begin{array}{c}\mathrm{U} \\
\mathrm{L} \\
\mathrm{CI}\end{array}$ & \\
\hline $\begin{array}{l}\text { Con- } \\
\text { stant }\end{array}$ & $\begin{array}{c}1.505 \\
0\end{array}$ & .3097 & 4.8593 & .0000 & .8911 & $\begin{array}{c}2 . \\
11 \\
89\end{array}$ & \\
\hline EI & .6939 & .0743 & 9.3423 & .0000 & .5467 & $\begin{array}{c}.8 \\
41 \\
2\end{array}$ & \\
\hline $\begin{array}{l}\text { Out- } \\
\text { come }\end{array}$ & JS & & & & & & \\
\hline \multicolumn{8}{|c|}{ Model Summary } \\
\hline & $\mathrm{R}$ & R-sq & $\mathrm{F}$ & df1 & $\mathrm{df} 2$ & $\mathrm{p}$ & \\
\hline & .7734 & .5981 & $\begin{array}{c}160.740 \\
4\end{array}$ & 1.0000 & $\begin{array}{c}108.00 \\
00\end{array}$ & .0000 & \\
\hline \multicolumn{7}{|l|}{ Model } & \\
\hline & coeft & & & & LLCI & ULCI & \\
\hline
\end{tabular}

\begin{tabular}{|c|c|c|c|c|c|c|}
\hline $\begin{array}{l}\text { con- } \\
\text { stant }\end{array}$ & .4011 & .3203 & 1.2523 & .2132 & -.2338 & $\begin{array}{c}1.036 \\
1\end{array}$ \\
\hline EI & .9740 & .0768 & 12.6783 & .0000 & .8217 & $\begin{array}{c}1.126 \\
3\end{array}$ \\
\hline $\begin{array}{l}\text { Out- } \\
\text { come }\end{array}$ & $\mathrm{OP}$ & & & & & \\
\hline \multicolumn{7}{|c|}{ Model Summary } \\
\hline & $\mathrm{R}$ & R-sq & $\mathrm{F}$ & df1 & df2 & $\mathrm{p}$ \\
\hline & .9604 & .9224 & $\begin{array}{c}419.931 \\
5 \\
\end{array}$ & 3.0000 & $\begin{array}{c}106.00 \\
00\end{array}$ & .0000 \\
\hline \multicolumn{7}{|l|}{ Model } \\
\hline & coeff & se & $\mathrm{t}$ & $\mathrm{p}$ & LLCI & ULCI \\
\hline $\begin{array}{l}\text { con- } \\
\text { stant }\end{array}$ & $\begin{array}{c}- \\
.3812\end{array}$ & .1675 & -2.2759 & .0249 & -.7132 & $\begin{array}{c}- \\
.0491\end{array}$ \\
\hline OCB & .0148 & .0499 & .2974 & .7667 & -.0841 & .1138 \\
\hline JS & .8784 & .0482 & 18.2056 & .0000 & .7827 & .9741 \\
\hline EI & .2152 & .0605 & 3.5595 & .0006 & .0954 & .3351 \\
\hline \multicolumn{7}{|c|}{ Direct effect of $\mathrm{X}$ on $\mathrm{Y}$} \\
\hline & $\begin{array}{c}\text { Ef- } \\
\text { fect }\end{array}$ & SE & $\mathrm{t}$ & $\mathrm{p}$ & LLCI & ULCI \\
\hline & .2152 & .0605 & 3.5595 & .0006 & .0954 & .3351 \\
\hline \multicolumn{7}{|c|}{ Indirect effect of $\mathrm{X}$ on $\mathrm{Y}$} \\
\hline & $\begin{array}{l}\text { Ef- } \\
\text { fect }\end{array}$ & $\begin{array}{c}\text { BootS } \\
\text { E }\end{array}$ & $\begin{array}{c}\text { BootLL } \\
\text { CI }\end{array}$ & $\begin{array}{l}\text { Boot- } \\
\text { ULCI }\end{array}$ & & \\
\hline Total & 8659 & .0750 & .7273 & 1.0192 & & \\
\hline $\mathrm{OCB}$ & .0103 & .0317 & -.0566 & .0733 & & \\
\hline JS & 8556 & .738 & .7179 & 1.0021 & & \\
\hline
\end{tabular}

\subsection{Role of Emotional Intelligence}

Based on the total based of effects value of emotional intelligence on organisational performance, it was found that both organisational citizenship behaviour and job satisfaction influenced the outcome (ie organisational performance). Job satisfaction has a higher impact to the relationship as compared to organisational citizenship behaviour. The impact of emotional intelligence increased from 0.2152 to 0.8556 . Job satisfaction is an employee's view point or feelings with regards to the workplace. This could include the work assigned and also the support from their fellow colleagues and supervisors. According to (16), job satisfaction can be described as "an affective reaction and attitude" of employees towards their job. Employees who are happy and contented at their workplace tends to develop a sense of passion and positive reaction. They tend to portray good behaviours and characteristics. Employees who are satisfied with their jobs tend to work longer at the organisation. When employees have that "affective reaction", they tend to develop attachments and a sense of belongingness to the workplace.

There are 5 sets of emotional competencies. They are emotional recognition and expression; understanding others emotions; emotions direct cognition; emotional management and emotional control. These 5 competencies can be divided into 2 components, ie, interpersonal and intrapersonal skills. In terms of the interpersonal skills, emotional intelligence enhances the workplace atmosphere. The level of mutual understanding and cooperation increases with the level of emotional intelligence. Employees would be able to identify and respond to their colleague's feelings and employees are also able to express their thoughts better. Being able to express their thoughts is one of the fundamentals of good teamwork. Good teamwork improves the level of productivity and quality of product. In terms of the intrapersonal skills, employees are able to manage their emotions and are able to withstand strong negative power. In tight work schedules, employees may be required to work long hours. A good sense of emotional handling helps to manage stress. A good sense of stress management is vital as it may have an impact on the workplace environment if its not managed properly. 


\section{Conclusion}

The purpose of this study is to examine the role of emotional intelligence to organisational performance with 2 mediating variables. The 2 mediating variables are job satisfaction and organisational citizenship behaviour. It was found that the 2 mediating variables does enhance the relationship between emotional intelligence and organisational performance. From the 2 mediating variables, it was found that job satisfaction had a higher influence in the relationship. The role of emotional intelligence has increased further from the influence of both job satisfaction and organisational citizenship behaviour. Emotional intelligence improves the interpersonal and intrapersonal skills of the employees in the organisation. The current study focuses on a successful organisation in a plastic manufacturing industry. And the study's framework uses 4 variables, ie, emotional intelligence, organisational performance, job satisfaction and organisational citizenship behaviour. The results cannot be generalised to all organisations but only to those having similar characteristics as the current organisation. Future studies may include other organisations from other industries to study the effects of the current variables.

\section{References}

[1] Baluch N, Abdullah CS \& Mohtar S (2013). Volatility in Malaysian skilled labour market: Evaluating manufacturing sector. European Journal of Business and Management, 5(6), 166-174.

[2] Cartwright S \& Pappas C (2008). Emotional Intelligence, its measurment and implications for the workplace. International Journal of Management Reviews, 149-171.

[3] Chiu WB \& Ng FF (2015). The mediation influence of job satisfaction on organisational commitment amongst quantity surveyors. Construction Economics and Building, 15(1)

[4] Goleman D (1995). Emotional Intelligence. New York: Bantam.

[5] Hashemi SM, Nadi HK., Hosseini SM \& Rezvanfar A (2012). Explaining agricultural personnel's entrepreneur behaviour: The mediating effects of job satisfaction and organisational commitment. International of Business and Social Science (396), 299-308.

[6] Ismail R, Rosa A \& Sulaiman, N (2011).Globalisation and labour productivity in the Malaysian manufacturing sector. Review of Economics \& Finance, 76-86.

[7] Krishnan R, Ismail IR \& Samuel R (2013). The mediating role of work engagement in the relationship between job autonomy and citizenship performance. World Journal of Social Science, 3(3 May 2013), 120-131.

[8] Lee YJ, Lee IC \& Lin CL (2014). The effects of employees' satisfaction and leadership styles on organisational performance: Organisational commitment as a dual mediator. Asian Journal of Empirical Research, 4(2), 104-124.

[9] Mamat @ Mohd Nor F \& Roslan S (2012). Critical Success Factors (CSFs) on technology transfer effectiveness in manufacturing industry: A critical review. International Journal of Business, Economics and Law, 1, 163-170.

[10] Mehboob F \& Bhutto NA (2012). Job satisfaction as a predictor of Organizational Citizenship Behaviour a study of faculty members at business institutes. Interdisciplinary Journal of Contemporary Research in Business, 3(9), 1447-1455.

[11] Palmer B \& Stough C (2001). Swinburne University Emotional Intelligence Test Interim Technical Manual. Melbourne: Swinburne University.

[12] Podsakoff PM, Mackenzie SB, Moorman RH, \& Fetter R (1990). Transformational leaders behaviour and their effects on followers' trust in leader, satisfaction and organisational citizenship behaviour. Leadership Quarterly, 1, 107-142.

[13] Rahim SH \& Malik MI (2010). Emotional intelligence and organisational performance: A case study of banking sector in Pakisatan. International Journal of Business and Management. 5(10), 191-197

[14] Rucker DD, Preacher KJ, Tormala ZL \& Petty RE (2011). Mediation analysis in social psychology: Current practices and new recommendations. Social and Personality Compass, 5/6, 359-371.

[15] Warner PD (1973). A comparative study of three patterns of staffing with the Cooperative Extension Servuce organisation and their association with organisational structure, organisational effective- ness, job satisfaction and role conflict. Columbus: Ohio State University.

[16] Zaman FT \& Rahman MS (2013). Job Satisfaction of women in the corporate world. Interdisciplinary Journal of Contemporary Research in Business, 5(8), 9-22. 